\title{
低サイクル疲労における平均応力効果とサイクリッククリープ*
}

\author{
原田昭 治*1, 遠藤 達 雄*1 \\ 福 島 良 博*1, 安 東 秀 夫*2
}

\section{The Effect of Cyclic Strain-Induced Creep on the Low-cycle Fatigue of a Medium Carbon Steel under Imposed Mean Stress}

\begin{abstract}
Shoji HARADA, Tatsuo ENDO, Yoshihiro FUKUSHIMA, and Hideo ANDO

In a nominal or engineering stress-controlled low-cycle fatigue test, cyclic strain-induced creep (C. C) often advances when a mean stress is imposed. To examine rigorously the effect of this C. C behaviour on fatigue strength, true stress-controlled low-cycle fatigue tests were conducted on a medium carbon steel under imposed either tensile or compressive mean stress. The effects of a cyclic stress-strain relationship and C. C behaviour-produced axial plastic strain $\left(\varepsilon_{m}\right)$ on fatigue strength were examined. Those effects were also examined from the viewpoint of microcrack initiation and propagation. The following results were obtained: (1) The cyclic plastic strain versus stress amplitude relation at the steady cyclic stress-strain state showed a power type relationship, irrespective of tensile or compressive mean stress. (2) An increase of $\varepsilon_{m}$ per cycle at half of the fatigue life was expressed by a power law of maximum tensile or compressive stress. (3) A modified Manson-Coffin relation, inclusive of a parameter of mean stress, was proposed. (4) The effect of the C. $\mathrm{C}$ behaviour on the fatigue strength was estimated on the basis of a microcrack growth law-aided approach previously developed.
\end{abstract}

Key Words: Fatigue, Low-cycle Fatigue, Mean Stress, Cyclic Strain-induced Creep, Microcrack Initiation and Propagation, True Stress

\section{1. 緒 言}

疲労寿命に及ぼす平均応力の影響を明らかにするこ とは, 実働荷重下の構造部材の疲労寿命予測問題とも 関連して実用上重要な問題であり，これまでに数多く の研究が行われている．従来の研究報告を概観すると 高サイクル疲労に関連した研究が数多く見受けられる が，低サイクル疲労に関する検討例は比較的少ない。 高サイクル疲労の場合, 平均応力の影響は大略以下の ように理解されている，すなわち，高サイクル疲労で は，き裂発生過程は繰返しせん断応力によって支配さ れるため平均応力の影響はほとんど認められない(1). しかし，き裂伝ぱ過程はき裂面に作用する垂直応力の 大きさによって支配されるため, 平均応力の影響が顕 著に現れ，また破壊力学的手法を用いてその影響を定 量的に評価することが可能である。

さて, 繰返し荷重レベルが材料の降伏点を超える低 サイクル疲労の場合, 平均応力作用下では, いわゆる サイクリッククリープ (Cyclic creep, 以下 C. C と称 す）現象が生起する場合があり，平均応力効果の評価

* 昭和 62 年 11 月 20 日 第 949 回講演会において講演, 原稿 受付 昭和 62 年 5 月 20 日.

*1 正員，九州工業大学 (\$804 北九州市户畑区仙水町 1-1).

*2 准員, 三菱重工業(株)（画850-91 長崎市飽の浦町 1-1）.
は一般に高サイクル疲労の場合に比べ困難である．周 知のように低サイクル疲労試験は荷重制御またはひず み制御方式で行われるが, 荷重制御の場合, 平均応力 作用下ではこの C. C 現象は顕著となる。一般にひずみ 制御方式下では平均ひずみが作用してもC.C現象が ほとんど生起せず, 平均ひずみの影響評価法も大略確 立されているようである(2) (6). 一方, 荷重制御の場合, 平均応力効果について検討した報告例がいくつか見ら れるが(7)〜(13)特にC.C. 現象と関連づけて研究した例は 少なく, 白鳥らによる一連の研究 ${ }^{(10) \sim(13)}$ が見られる程 度である. 彼らは定荷重および定応力（繰返し真応力 振幅一定）試験の結果を比較検討することにより，C. C 現象と疲労寿命の関係について一定の解釈を与えて いる.

ところで, 荷重制御方式の場合, 平均応力作用下で C. C 現象が進行すると, 当然公称応力振幅は一定でも 真応力振幅は変化するので, 平均応力の影響を正しく 評価し得ない場合も起こり得ることが考えられる。そ こで著者らは先にマイコンを利用した真応力制御方式 の疲労試験システムを試作し(14)，C.C 現象や疲労寿命

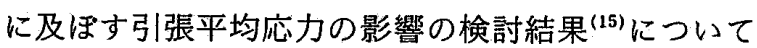
報告した，本報では圧縮平均応力の場合も加え，引張 りおよび圧縮平均応力作用下での C. C 現象と疲労寿 
命の関係について検討を加えた．さらに著者らが数年 来進めている, 微小き裂の発生, 伝ぱに基づいて低サ イクル疲労寿命を評価する一連の研究(16) (19)の一環と して, 本研究でも平均応力効果を微小き裂の発生・伝 ぱ特性の評価を通じて把握することを試みた。

\section{2. 実験材料および方法}

実験材料および方法についてはすでに前報 ${ }^{(14)(15)}$ 詳述したので,ここでは必要事項を簡潔に述べるに止 める。供試材は市販の S 45 C 圧延丸棒（直径 $22 \mathrm{~mm}$, 下降伏点 $304 \mathrm{MPa}$ ，抗張力 $580 \mathrm{MPa}$ ，しぽ $49.4 \%$ ) で, 素材に焼なまし熱処理 $\left(844^{\circ} \mathrm{C}, 1 \mathrm{~h}\right)$ を施した後, 砂 時計形試験片形状（全長 $106 \mathrm{~mm}$, 最小断面部直径 8 $\mathrm{mm}$ )に機械加工した. 試験片表面を\#06 まで紙やすり 仕上げした後表面観察用に軽く電解研磨を施した。 た観察位置を限定するため, 最小断面部に応力集中に 影響を及ぼさない浅い微小切欠きを設けた。

試験片最小断面部の直径方向変位を伸び計を用いて 検出し，その伸び (ひずみ) 信号とロードセルにより検 出した荷重信号を A/D 変換してマイコン (PC 8801) に導き, 繰返し真応力振幅一定の疲労試験を行った. 繰返し速度は $0.03 \sim 0.3 \mathrm{~Hz}$ で,また一定の繰返し数 ごとにレプリカを採取し, 光学顕微鏡観察を通じて微 小き裂発生・伝ぱ状況を追跡した，実験遂行上での前 報(14)との主な相違は用いた疲労試験機および伸び計 が異なることである。

真応力制御方式の疲労試験装置の精度を調べるた め, 真応力制御と公称応力制御（見かけ上の繰返し荷 重振幅一定)の疲労試験を行い, 比較検討した. 応力振 幅 $\Delta \sigma / 2$ が $370 \mathrm{MPa}$ で平均応力 $\sigma_{m}$ が $50 \mathrm{MPa}$ の場合 の結果を図 1 に示す.ただし，緃軸は繰返し真応力の 最大值 $\sigma_{\max } お$ よび最小值 $\sigma_{\min }$ の絶対值 $\left|\sigma_{\min }\right|$, 横軸 は破断繰返し数比 $N / N_{f}$ をそれぞれ示す。図より明ら かなごとく, 真応力制御の場合, $\sigma_{\max }, \sigma_{\min }$ は $N / N_{f}$ に無関係に設定值にほほ一致しているのに対し，公称 応力制御では応力の上下限は繰返しに伴う C.C 現象 の進行により増加し, 特に寿命の初期および後期で変 化が大きい.

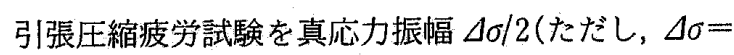
$\left.\sigma_{\max }-\sigma_{\mathrm{min}}\right)$ を一定にして平均真応力 $\sigma_{m}$ を正と負に 変化させた場合, 反対に $\sigma_{m}$ を一定にして $\Delta \sigma / 2$ を変 えた場合について実施した，表 1 に本研究で行った $\Delta \sigma / 2$ と $\sigma_{m}$ の組合せについての試験条件を示す. C.C 現象によって生じる一方向変形（軸方向の平均塑性ひ ずみ $\left.\varepsilon_{m}\right)$ と $\Delta \sigma / 2, \sigma_{m}$ との関係および Manson-Coffin 形寿命則と $\sigma_{m}$ の関係について検討した.なお，以下の
記述においては特に断わらない限り，応力振幅および 平均応力は, 真応力振幅抽よび平均真応力を表すもの とする。

\section{3. 実 験 結 果}

\section{$3 \cdot 1$ 繰返し応力ーひずみ特性と $\Delta \sigma / 2, \sigma_{m}$ の関係}

図 1 に示した結果から容易に理解されるように, C. $\mathrm{C}$ 現象進行下での繰返し応力振幅 $\Delta \sigma / 2$ を設定值に保 つことは, 負荷荷重の振幅を各繰返し数ごとに変化さ せることを意味する．したがって, 当然疲労寿命と密 接に関連する繰返し塑性ひずみ幅 $\Delta \varepsilon_{p}$ も繰返しに伴 って変化する, 図 2 (a)，（b)にそれぞれ, 応力振幅 $\Delta \sigma / 2$ を一定 $(=370 \mathrm{MPa})$ にして平均応力を変えた場 合, 反対に $\sigma_{m}$ を一定 $(=-40 \mathrm{MPa})$ にて $\Delta \sigma / 2$ を変 化させた場合の繰返しに伴う $\Delta \varepsilon_{p}$ の変化を示す. $\sigma_{m} \geqq$ 0 の場合も含め, 他の $\Delta \sigma / 2$ と $\sigma_{m}$ の組合せ (表 1 参照) の場合にも $\Delta \varepsilon_{p}-N / N_{f}$ 関係は同図とほぼ同じ傾向を 示した. $\Delta \varepsilon_{p}$ は寿命の初期に繰返し硬化によって急減 し，その後漸減または飽和の傾向を示し，寿命の最終 段階で急増している. 飽和時の $\Delta \varepsilon_{p}$ と $\Delta \sigma / 2$ および $\sigma_{m}$ の関係の特徴として, ( i ) $\Delta \sigma / 2$ 一定の場合, $\Delta \varepsilon_{p}$ は $\sigma_{m}=0$ の場合が最も大きく, $\sigma_{m}$ が正と負に変化して

表 1 疲労試験時の応力条件- $\Delta \sigma / 2$ と $\sigma_{m}$ の組合せ

\begin{tabular}{|c|c|c|c|c|c|c|}
\hline$\Delta 0 / 2$ & 0 & 50 & 80 & -30 & -40 & -50 \\
\hline 340 & 0 & - & - & & 0 & 0 \\
\hline 370 & 0 & 0 & - & & - & 0 \\
\hline 400 & $\Delta$ & - & - & $\Delta$ & $\Delta$ & $\Delta$ \\
\hline 430 & $\searrow$ & 0 & $\Delta$ & - & - & - \\
\hline 460 & $\nabla$ & $\nabla$ & $\nabla$ & - & - & - \\
\hline 490 & $\diamond$ & 0 & - & - & - & - \\
\hline 540 & $\diamond$ & - & - & - & - & - \\
\hline
\end{tabular}

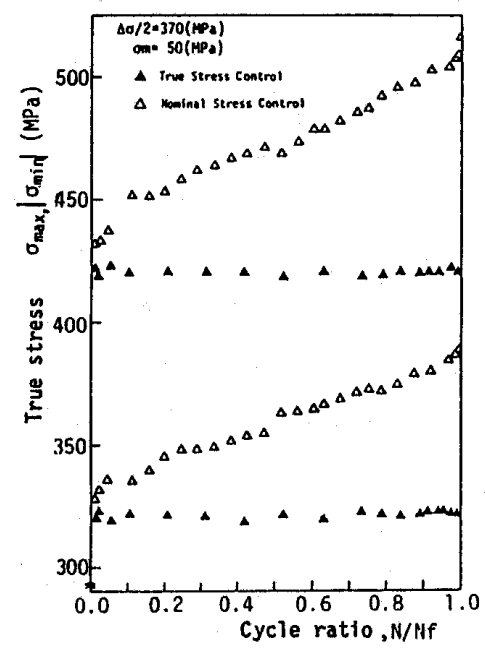

図 1 繰返しに伴う応力振幅 $\Delta \sigma / 2$ の変化公称応力制御と真応力制御の比較 
も $\sigma_{m}$ のレベル依存形の明確な差異は現れない。（ii） $\sigma_{m}$ 一定の場合, $\sigma_{m}$ が正負の場合ともに $\Delta \varepsilon_{p}$ は $\Delta \sigma / 2$ のレベル増加とともに大きくなる明確な傾向を示す.

周知のように $\Delta \varepsilon_{p}$ は Manson-Coffin 則を介して寿 命を直接評価できるパラメータであるが, 本研究のよ うに真応力制御方式下では, $\Delta \varepsilon_{p}$ が $\Delta \sigma / 2$ および $\sigma_{m}$ に依存して変化するため，その取扱いに注意する必要 がある. $\Delta \varepsilon_{p}$ と $\Delta \sigma / 2$ および $\sigma_{m}$ の相互関係を導くた め,よく行われているように繰返しに伴う $\Delta \varepsilon_{p}$ の減少 傾向がほぼ定常となる寿命の $50 \%$ \%おる $\Delta \varepsilon_{p}$ を採 用して代表することにする. 前報 ${ }^{(15)}$ と同様, 縦軸に $\Delta \varepsilon_{p}$, 横軸に $\Delta \sigma / 2$ をとつて両者を両対数線図上にプロ ットし，正負の各 $\sigma_{m}$ に対して整理すると，各 $\sigma_{m}$ に対 して $\Delta \varepsilon_{p}-\Delta \sigma / 2$ 関係は平行な直線群として表される. その結果, 正負の $\sigma_{m}$ に対し, $\Delta \varepsilon_{p}-\Delta \sigma / 2$ 関係として次 式を得る.

$$
\Delta \varepsilon_{p}=A(\Delta \sigma / 2)^{m}
$$

ただし， $m:$ 材料定数, $A: \sigma_{m}$ の関数,であり, $m, A$ は本研究の場合, 次式で与えられる.

$$
\begin{aligned}
m & =3.03\left(\sigma_{m} \geqq 0, \sigma_{m}<0\right) \cdots \cdots \cdots \ldots . \\
A & = \begin{cases}10^{-4,60 \times 10^{-3} \sigma_{m-9.98}} & \left(\sigma_{m} \geqq 0\right) \\
10^{5.43 \times 10^{-3} \sigma_{m-9.98}} & \left(\sigma_{m}<0\right)\end{cases}
\end{aligned}
$$

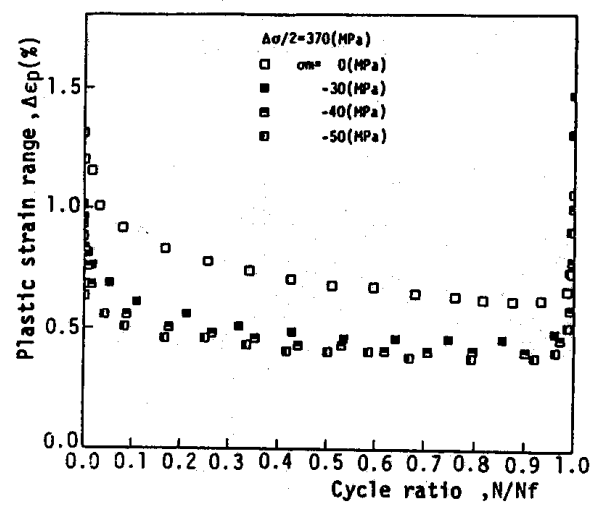

(a) $\Delta \sigma / 2$ 一定で $\sigma_{m}$ を変えた場合

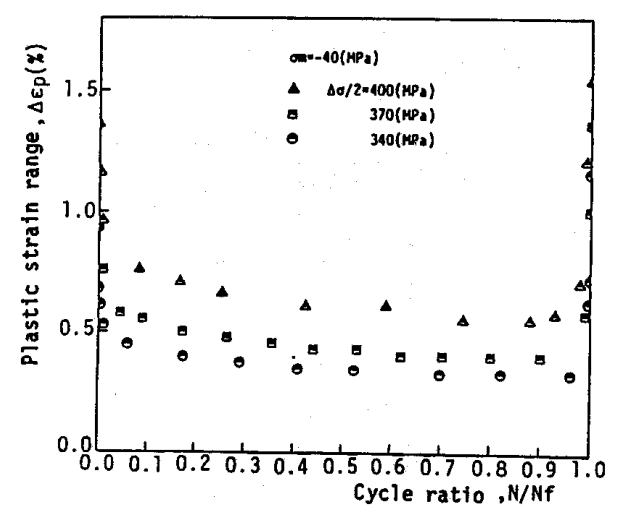

（b） $\sigma_{m}$ 一定で $\Delta \sigma / 2$ を変えた場合

図 2 繰返しに伴う塑性ひずみ幅 $\Delta \varepsilon_{p}$ の変化
なお，上式で $\sigma_{m} \geqq 0$ の $m, C$ が前報の結果とわずか異 なるが,これは使用した試験機および伸び計の違いに 起因するものと考えられる。

3.2 C. C 現象進行下で生じる一方向变形ととの評 価 平均応力作用下でのC.C 現象進行の結果生じる 一方向変形, すなわち平均塑性ひずみ $\varepsilon_{m}$ (軸方向累積塑 性ひずみ)は，疲労寿命に大きな影響を及ほすため，そ の定量的評価を行った. 定量化の方法は前報(15) とほほ 同じであるのでその詳細はここでは省略するが, $\sigma_{m} \geqq$ 0 および<0に対して $\varepsilon_{m} \geqq 0$ およびく0であるので， 平均応力の符号によって多少取扱いを変える必要があ る.まず，各 $\Delta \sigma / 2 ， \sigma_{m}$ の組合せに対して繰返しに伴う $\varepsilon_{m}$ の変化 $\left(\varepsilon_{m}-N\right.$ 関係) を両対数線図上にプロットす ると, 両者は単調増加型の直線関係で表され，互いに 平行な直線群となる. 繰返し途中での $\varepsilon_{m}$ の増加を定 量的に評価するため, 繰返しに伴う $\varepsilon_{m}$ の増加速度 $d \varepsilon_{m} / d N$ を考える. 与えられた応力条件下での $d \varepsilon_{m} / d N$ は既述の $\Delta \varepsilon_{p}-N / N_{f}$ 関係 (図 2 参照) の場合と同様 $N_{f} /$ 2 での值で代表するものとする.また， $d \varepsilon_{m} / d N$ が絽返 し中の正負の最大応力，すなわち $\sigma_{m} \geqq 0$ では $\sigma_{\max }$,

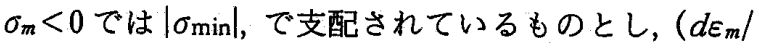
$d N)\left.\right|_{N_{f / 2}-\sigma_{\max }}$ または $\left|\sigma_{\min }\right|$ 関係を両対数線図上に表 示すると, 図 3 に示すごとく, 両者の間には直線関係 が成立し，また $\sigma_{m} \geqq 0$ および $\sigma_{m}<0$ の結果がほぼ一 致する. 同図より, 両者の間には次式で示される関係 が成立する。

$$
\left.\frac{d \varepsilon_{m}}{d N}\right|_{N / 2}=K \sigma_{\max }{ }^{n}\left(\sigma_{m} \geqq 0\right),=K\left|\sigma_{\min }\right|^{n}\left(\sigma_{m}<0\right)
$$

ただし $K, n$ は定数で

$$
K=1.19 \times 10^{-33}, n=10.6
$$

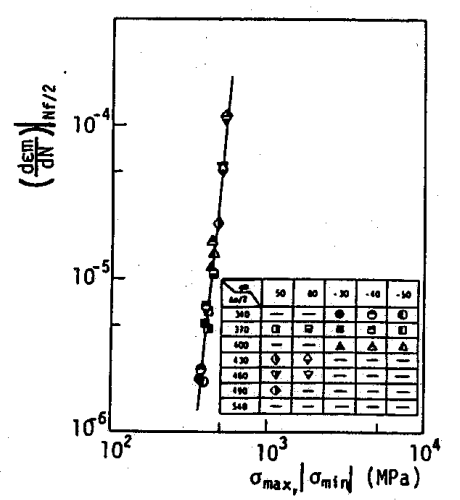

図 $\left.3\left(d \varepsilon_{m} / d N\right)\right|_{N_{f} / 2}$ と最大応力 $\left[\sigma_{\max }\left(\sigma_{m}>0\right)\right.$ または $\left.\left|\sigma_{\mathrm{min}}\right|\left(\sigma_{m}<0\right)\right]$ 
$3 \cdot 3$ 疲労寿命に及ぼす平均応力の影響 図 4 に $\Delta \sigma / 2-N_{f}$ 関係で表した疲労寿命線図を示す. 図 4 にお いて, 破断寿命は $\sigma_{m}=0$ の結果に対し，正負の平均応 カが作用すると，いずれも長寿命側に移行している. ただし， $\sigma_{m}$ 依存形の寿命差の傾向は認められないよ うである. $\sigma_{m}<0$ の場合はともかく, $\sigma_{m}>0$ で疲労寿 命が $\sigma_{m}=0$ のそれより長寿命側となるのは，通常の定 荷重 (公称応力振幅一定) 制御方式の疲労試験結果か ら予想されるのと反対の傾向で，一見奇異である。こ れは図 1 および図 2 に示したように, 真応力制御と公 称応力制御における C. C 挙動の相違による塑性ひず み振幅や軸方向累積塑性ひずみの挙動の違いによるも のと考えられる。

図 5 に $\Delta \varepsilon_{p}-N_{f}$ 関係で表した邫命線図を示す．ただ し, $\Delta \varepsilon_{p}$ は図 2 および式 (1)の誘導を参照して, $N_{f} / 2$ における值を用いた。同図より， $\Delta \varepsilon_{p}-N_{f}$ 関係で表示し た場合には, $\Delta \sigma / 2-N_{f}$ 関係表示の場合とは逆に $\sigma_{m}=0$ に対して $\sigma_{m}>0 ， \sigma_{m}<0$ の結果がいずれも短寿命側と なっている. 完全両振りに比べ, 平均応力作用下で寿 命が低下する理由は，C.C 現象進行による軸方向塑性 ひずみの累積; すなわち, 平均塑性ひずみ $\varepsilon_{m}$ の増加 による見かけ上の材料の破断延性 $\varepsilon_{f}$ の低下によるも のと考えられる. そこで, 平均応力効果をパラメー夕 $\varepsilon_{m}$ を用い, Manson-Coffin 形の寿命則を通じて評価 するため，以下のような検討を行った．図 5 において, $\sigma_{m}=0$ の結果を直線回帰すると, 次式で表される Manson-Coffin 形の寿命則を得る。

$$
\Delta \varepsilon_{p} \cdot N_{f}^{0.533}=0.673
$$

$\sigma_{m}=0$ の場合には一方向変形はほとんど起こらない もの $\left(\varepsilon_{m}=0\right)$ と仮定し, 正負 $\sigma_{m}$ の作用下での $\varepsilon_{m}$ の増 加が寿命低下，すなわち $\varepsilon_{f}$ の減少をもたらすものと して $\left(0.673-\Delta \varepsilon_{p} N_{f}^{0.533}\right) /\left.\left(d \varepsilon_{m} / d N\right)\right|_{N_{f} / 2}$ と $N_{f}$ の関係を 両対数線図上にプロットすると図 6 のようになる.両 者は $\sigma_{m}>0,<0$ の場合についてほほ 1 本の直線関係で 近似され，次の実験式を得る。

$$
\Delta \varepsilon_{p} \cdot N_{f}^{0.533}+\left.C \cdot\left(d \varepsilon_{m} / d N\right)\right|_{N_{s} / 2} \cdot N_{f}^{\beta}=0.673
$$

ただし

$$
\left\{\begin{array}{l}
C=0.422, \beta=1.213\left(\sigma_{m}>0\right) \\
C=6.69 \times 10^{-6}, \beta=2.268\left(\sigma_{m}<0\right)
\end{array}\right.
$$

上式を平均応力作用下での C. C 現象の影響を考慮し た修正 Manson-Coffin 則と呼ぶことにする. 図 7 に以 上のようにして求めた修正 Manson-Coffin 則を用い て算出した寿命と実測值の比較を示す。 $\sigma_{m}$ が正負の場 合ともに両者がほぼ一致していることがわかる.
$3 \cdot 4$ 微小き裂の発生, 伝ぱに基づく平均応力効果 の評価 前節までに疲労寿命に及ぼす平均応力およ びC.C 現象の影響を巨視力学的因子 $\Delta \sigma / 2, \sigma_{m}, \Delta \varepsilon_{p}$ および $\varepsilon_{m}$ によって評価することを試みた。ところで， 著者らは低サイクル疲労寿命を微小き裂の発生・伝ぱ

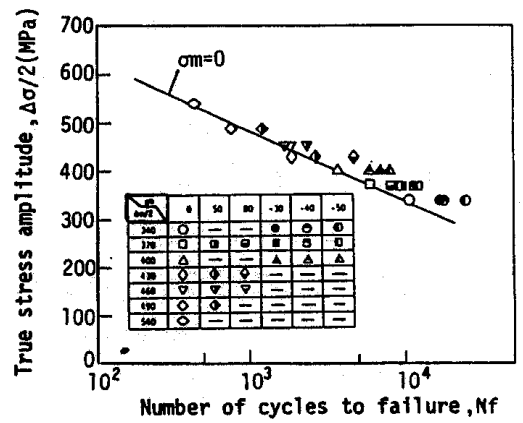

図 4 破断寿命線図 $\left(\Delta \sigma / 2-N_{f}\right.$ 関係)

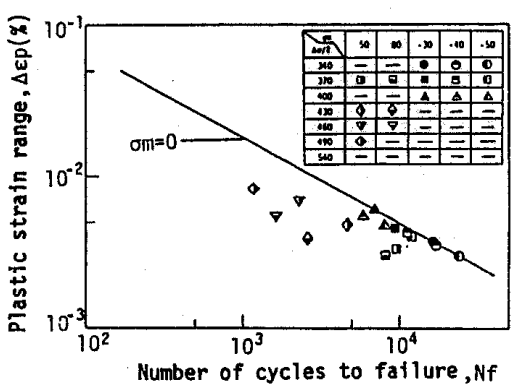

図 5 破断寿命線図 $\left(\Delta \varepsilon_{p}-N_{f}\right.$ 関係 $)$

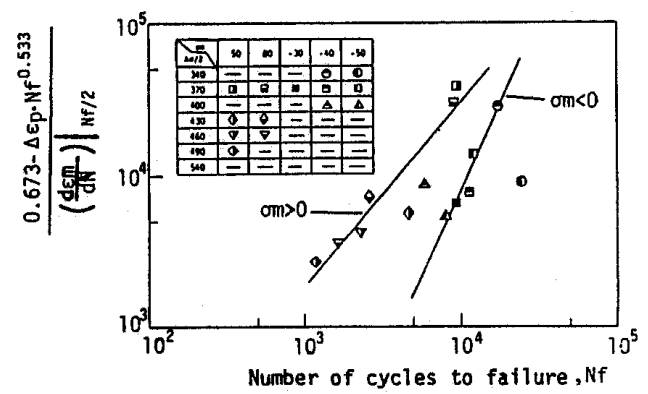

図 $6 \quad\left(0.673-\Delta \varepsilon_{p} \cdot N_{f}^{0.533}\right) /\left.\left(d \varepsilon_{m} / d N\right)\right|_{N_{s} / 2}-N_{f}$ 関係

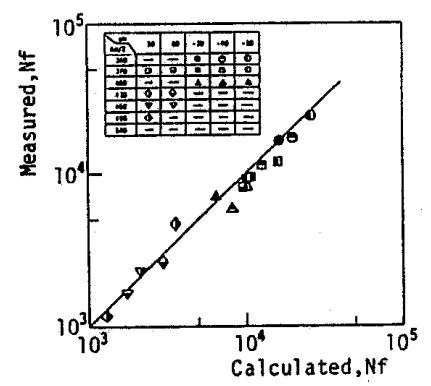

図 7 修正 Manson-Coffin 則を用いて算出 した寿命と実測値との比較 
に基づいて評価する一連の研究(16) (19)を行っている. そこで, 本節では, 平均応力効果を同様な立場から検 討した結果について述べる.

レプリカ法を用いて微小き裂の発生, 伝ぱ挙動の連 続観察を行った。まず, 結晶粒オーダの微小き裂は，前 報(16) (19)でのひずみ制御試験の場合と同様, 全寿命の ごく初期に発生し，また，平均応力作用の有無は無関 係であった．主き裂が結晶粒オーダから破断直前の約 $2 \mathrm{~mm}$ の長さに成長するまでの伝ば過程を追跡し, 平 均応力作用下での微小き裂伝ぱ特性を明らかにした. 平均応力作用下でも微小き裂伝ば挙動は定ひずみ振幅 条件で行った前報の結果とほほ同じで, 主き裂の単一 き裂形優先伝ぱではなく，伝ぱの途中で他の分布き裂 と合体して成長する例も観察された。き裂の合体成長 問題も含め, 主き裂の伝ぱ則の誘導についてはすでに 前報(16)(17)で詳述したので,ここでは簡潔に述べる。平 均応力の有無とは無関係に微小き裂伝ぱ則の誘導方法 は同じであるので, ここでは $\sigma_{m}=0$ の場合で代表して 述べる.

$\sigma_{m}=0$ の場合, 各応力振幅下でのき裂伝ぱ曲線（き 裂長さ $l$-繰返し数 $N$ 関係) より, き裂伝ぱ速度 $d l l d N$ に関して次式で表される関係式を得た。

$$
\left\{\begin{array}{l}
d l l d N \propto 10^{7.47 \times 10^{-3} \cdot(4 \sigma / 2)} \cdot f(l) \\
f(l): l \text { の関数 }
\end{array}\right.
$$

さらに,き裂伝ぱ速度とき裂長さの関係を得るため, $(d l / d N) / 10^{7.47 \times 10^{-3.3}(4 \sigma / 2)}-l$ 関係を両対数線図上にプロ ットすると，前報 ${ }^{(16)(17)}$ の定ひずみ振幅試験結果と同 様, 各応力振幅下の結果がこう配がほほ 1 の 1 本の直 線で近似された.すなわち, $d l / d N \propto l$ となり，次の関 係式が得られた。

$$
\frac{(d l l d N)}{10^{7.47 \times 10^{-3} \cdot(\Delta \sigma / 2)}}=1.58 \times 10^{-6} \cdot l
$$

$l_{0}, l_{f}$ をそれぞれき裂発生時 $\left(N=N_{0}\right)$ おるよび破断時 $\left(N=N_{f}\right)$ のき裂長さとして，上式を積分し，かつ以下 の条件

$$
\begin{aligned}
& l_{0}=19 \mu \mathrm{m} \text { (平均パーライト粒径) } \\
& l_{f}=8 \mathrm{~mm} \text { (試験片直径) } \\
& N_{0}=0\left(\because N_{0} \ll N_{f}\right) \\
& \text { を代入すると最終的に次式が得られた. } \\
& \ln _{n} N_{f}=6.58-7.47 \times 10^{-3}(\Delta \sigma / 2) \cdots \cdots
\end{aligned}
$$

式(1)を考慮すると，上式は式(5)で表される Manson-Coffin 形寿命則とほほ同じ形の寿命則を微小 き裂伝ぱ則に基づいて導けたことが理解される. 正負 の平均応力が作用した場合, 同様にしてそれぞ机 $\sigma_{m}$ に対して式(8)，(9)と同形のき裂伝ぱ則および 寿命則を導くことができるが，その詳細は省略する。
図 8 に以上のように微小き裂伝ぱ則に基づいて算出し た寿命を実測值と比較したものを示す. 各平均応力の 場合とも寿命の算出值と予測がほぼ一致していること がわかる.

\section{4. 考 察}

低サイクル疲労試験は通常荷重制御またはひずみ制 御方式で行われる.ひずみ制御のほうが荷重制御に比 べ, 実験が安定して行えること, 疲労寿命則と直接関

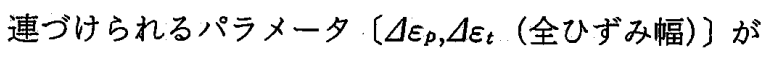
評価しやすいこと，などの理由により，一般に広く同 方式が採用されている。緒言でも述べたように,ひず み制御の場合には，平均ひずみが作用しても，C.C 現 象が起こらないので, 平均ひずみ効果の評価は比較的 容易である。例えば, 引張平均ひずみが作用した場合， 最も単純には破断延性 $\varepsilon_{f}$ が平均ひずみに相当する分 だけ見かけ上低下するとして, 完全両振りとして取扱 われている(2).

さて，荷重制御の場合，繰返し述べたごとく，公称 応力制御（定荷重振幅）と真応力制御では繰返し挙動 が異なる(図 1 参照)。それゅえ，特に本研究のように， 平均応力効果と C. C 現象の関係を議論するような場 合には，この点に留意した取扱いが必要である. 主と して学問的興味に基づく真応力制御試験は, 公称応力 制御試験に比べ結果の実用的意味は小さいが, 上述の ような問題の議論の定量化には不可欠である。

本研究では, 引張りおよび圧縮平均応力の疲労寿命 に及ぼす影響を C.C 現象の進行に注目して検討した。 $\sigma_{m}<0$ の場合, 圧縮最大応力 $\left(\sigma_{\mathrm{min}}\right)$ 時における試験片 座届の防止という実験上の制約のため，今回の実験で は $\sigma_{m}$ が比較的小さい範囲 $(-30 \sim-50 \mathrm{MPa})$ の資料 しか得ることができなかった。 そのため, 図 4 や図 5 に示した寿命線図および微小き裂伝ぱ則に基づいて予 測評価した寿命線図 (図 8)では, 結果のばらつきも考

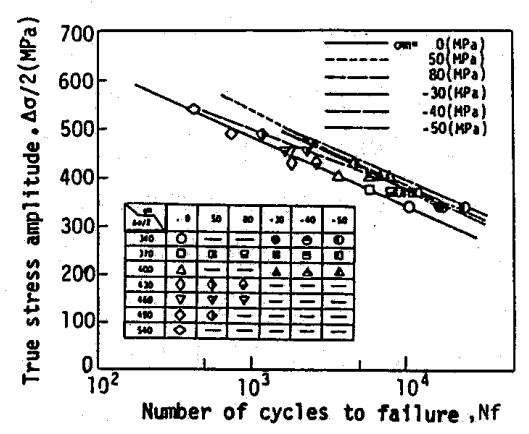

図 8 微小き裂伝ば則に基づいて予測評価 した寿命と実湘值との比較 
慮すれば, $\sigma_{m}$ の相違による寿命差を系統的に論じる 程度の明確な傾向差が現れていないものと解釈するの が自然である， $\sigma_{m}<0$ での $\sigma_{m}$ 依存形の平均応力効果 をより明確な形で引き出すには，今後 $\sigma_{m}$ がより大き い場合について検討を行う必要がある。

ともかく $\sigma_{m}=0$ に対して正負の平均応力が負荷さ れたとき, C. C 現象が進行して寿命が変化するのは前 節までに示した結果で明らかである．正負の平均応力 の疲労寿命に及济す影響を C.C 現象の進行と関連さ せて論じる場合, 以下の点について考慮する必要があ る.

（i） 真応力制御条件で平均応力作用下での塑性ひ ずみ幅 $\Delta \varepsilon_{p}$ の繰返しに伴う変化とその評価

（ii） $\sigma_{m}$ 作用下 C. C 現象の進行により生じる平均 塑性ひずみ（軸方向累積塑性ひずみ） $\varepsilon_{m}$ の繰返しに伴 う変化とその評価

$\sigma_{m}$ が正負の場合ともに(i)，（ii）の因子は寿命を 低下させる要因として作用する (図 5 参照)。（i）に関 して, $\Delta \varepsilon_{p}-N / N_{f}$ 関係（図 2) は，焼なましを施した 中・低強度鋼のひずみ制御試験で確認される公称応力 振幅 $\Delta \sigma / 2-N / N_{f}$ と見加り上正反対（ $\Delta \sigma / 2$ は寿命初期 に繰返しに伴って増加し，その後飽和した後寿命の最 終段階で低下) となっている. $\Delta \varepsilon_{p}-N / N_{f}$ 関係の傾向か ら判断して、ひずみ制御の場合の $\Delta \sigma / 2$ の評価の場合 と同様, 全寿命における平均的な值として $N_{f} / 2$ での $\Delta \varepsilon_{p}$ 值で代表することは妥当と考えられる。

一方，(ii）の $\varepsilon_{m}$ は C.C 現象の定量的解秎の基礎と なる主要パラメータの一つと考えられる．ここでは例 示を省略したが，既述のように， $\varepsilon_{m}-N / N_{f}$ 関係を両対 数線図上にプロットすると， $\Delta \sigma / 2$ を一定にして $\sigma_{m}$ を 变化させた場合, 互いに平行な直線群が得られた。す なわち, $\varepsilon_{m}$ は $\varepsilon_{m}=C N^{\alpha}(C$ は定数, $\alpha \neq 1)$ の関係で表 され，Nのべき乗に比例して増加した．したがって， 繰返しに伴う $\varepsilon_{m}$ の変化を考光た場合，基本的には $N_{f} / 2$ での值で代表する $\Delta \varepsilon_{p}$ の場合と同様な取扱いは できない.そこで本研究では，C.C現象進行による $\varepsilon_{m}$ の增加が直接 $\varepsilon_{f}$ の見かけ上の低下を引き起こすもの と仮定してその評価を行った。 その際, $N_{f} / 2$ での繰返 しに伴う $\varepsilon_{m}$ の增加率 (速度) $d \varepsilon_{m} / d N$ に着目し， $\left(d \varepsilon_{m} /\right.$ $d N)\left.\right|_{N / 22}$ を $\sigma_{\max }\left(\sigma_{m}>0\right)$ または $\left|\sigma_{\min }\right|\left(\sigma_{m}<0\right)$ と関連 づけて評価した。そして $\left.\left(d \varepsilon_{m} / d N\right)\right|_{N_{s / 2}}$ を繰返しに伴っ て $\varepsilon_{f}$ を見かけ上減少させるパラメータとして式 (6) で表される C.C 現象を考慮した修正 Manson-Coffin 則を導いた。図 6 に示した結果を見ると， $\sigma_{m}<0$ の結 果にばらつきが見られるものの, $\Delta \sigma / 2$ と $\sigma_{m}$ の組合せ を変えた際の $\left(0.673-\Delta \varepsilon_{p} N^{\alpha}\right) /\left.\left(d \varepsilon_{m} / d N\right)\right|_{N_{f} / 2}-N_{f}$ 関係
にはほほ直線関係が認められ，また $\sigma_{m}<0$ と $\sigma_{m}>0$ で直線のかたむきは異なる，同図の縦軸に採ったパラ メータ $\left(0.673-\Delta \varepsilon_{p} N^{0.533}\right) /\left.\left(d \varepsilon_{m} / d N\right)\right|_{N_{s} / 2}$ の内容は, $\left(0.673-\Delta \varepsilon_{p} N^{0.533}\right)$ はある $\Delta \varepsilon_{p}$ に対する $\sigma_{m}=0$ と $\sigma_{m}$ $>0$ または $\sigma_{m}<0$ の場合の寿命差, $\left.\left(d \varepsilon_{m} / d N\right)\right|_{N_{s / 2}}$ は既 述のように $N_{f} / 2$ に扔ける軸方向平均塑性ひずみ増加 速度（ $\Delta \sigma / 2$ およよび $\sigma_{m}$ に依存して変化）をそれぞれ表 す。したがってこのパラメータを単一の物理量と関連 づけて意味づけはできないが，結果として，C.C 現象 進行による見かけ上の $\varepsilon_{f}$ 低下を表す尺度として， $\left.\left(d \varepsilon_{m} / d N\right)\right|_{N / 2 / 2}$ は有効なパラメータであり，C.C現象を 考慮した修正 Manson-Coffin 則〔式(6)] が形式的に 導ける。な拉, $\sigma_{m}>0$ と $\sigma_{m}<0$ で直線が異なることか ら平均塑性ひずみ $\varepsilon_{m}$ の $\varepsilon_{f}$ の低下に及ぼす影響が異 なることが考えられるが, 平均圧縮応力レベルの高い 場合の検討が都合によりできなかったので, 本研究の 範囲では明らかでない。

$3 \cdot 4$ 節で述べた微小き裂の発生・伝ぱに基づく寿命 評価に関して, 微小き裂伝ぱ則の誘導方法は前 報 ${ }^{(16) \sim(19)}$ の定ひずみ振幅試験の場合と同様であるので その詳細はここでは省略した. 結果として, 平均応力 作用下の場合にも定ひずみ振幅試験結果と同様微小き 裂伝ぱ則は $\sigma_{m}$ が正負の場合ともに $d l l d N \propto l$,すなわ ちき裂伝ぱ速度がき裂長さの 1 次に比例する形をとっ た。また，き裂伝ぱ則より算出した寿命を実測值と比 較すると両者はほぼ一致した，ただし， $\sigma_{m}<0$ の場合， 同一応力振幅下で $\sigma_{m}$ を- $30,-40$ およびー $50 \mathrm{MPa}$ と変化させた際のき裂伝ぱ曲線はほほ一致し，微小き 裂伝ぱ則に基づいて算出した寿命には平均応カレベル 依存形の明確な寿命差の傾向は実測值の場合同様, 認 められなかった。

最後に, 本研究では低サイクル疲労に及ぼす平均応 力の影響を真応力制御試験の実施により，C.C 現象と の関連を通じて検討した．応力振幅 $\Delta \sigma / 2$ のレベルに 比べて平均応力 $\sigma_{m}$ のレベルが低い，比較的両振り応 力状態に近い応力条件での検討が大部分であったた め, 今後は $\Delta \sigma / 2$ に比べ $\sigma_{m}$ が相対的に大きい部分両 振り条件抢よび圧縮平均応力が大きい場合について追 加実験を行い, $\sigma_{m}<0$ と $\sigma_{m}>0$ での平均応力効果の相 違の有無について検討を深めたいと考えている.

\section{5. 結}

低サイクル岥労寿命に及ほすす平均応力 $\sigma_{m}$ の影響を 明らかにするため, 真応力制御方式の疲労試験を実施 し，サイクリッククリープ現象の進行に注目して検討 を行った. 真応力振幅 $\Delta \sigma / 2$ と正負の平均真応力 $\sigma_{m}$ の 
組合せを変えて行った実験結果を要約すると, 以下の ように結論づけられる。

（1）絽返し塑性ひずみ幅 $\Delta \varepsilon_{p}$ は寿命の初期およ び最終段階を除くとほぼ一定となり，破断寿命の $1 / 2$ での $\Delta \varepsilon_{p}$ と応力振幅の間には次式の関係が成立する.

$$
\Delta \varepsilon_{p}=A(\Delta \sigma / 2)^{m}
$$

ただし，

$$
\begin{aligned}
A & =10^{-4.60 \times 10^{-3} \cdot \sigma_{m}-9.98}, \quad\left(\sigma_{m} \geqq 0\right) \\
& =10^{5.43 \times 10^{-3} \cdot \sigma_{m}-9.98}, \quad\left(\sigma_{m}<0\right) \\
m & =3.03
\end{aligned}
$$

（2）平均応力作用下では繰返しに伴いC.C現象 が進行し, 軸方向平均塑性ひずみ $\varepsilon_{m}$ が生じる. $N_{f} / 2$ における繰返し数あたりの $\varepsilon_{m}$ の增加率 $\left.\left(d \varepsilon_{m} / d N\right)\right|_{N_{s / 2}}$ は最大引張応力 $\sigma_{\max }\left(\sigma_{m}>0\right)$ または最大圧縮応力 $\left|\sigma_{\min }\right|$ のべき乗に比例する.

(3) $\Delta \sigma / 2-N_{f}$ 関係で寿命を表示すると, $\sigma_{m}=0$ に 対して正負の平均応力が作用すると見かけ上寿命は延 びる.一方, $\Delta \varepsilon_{p}-N_{f}$ 関係で表示すると寿命差の傾向は 反対となる.

（4）正負の平均応力作用による軸方向平均塑性U ずみ $\varepsilon_{m}$ が破断延性 $\varepsilon_{f}$ を見が低下させるものと して，次式で表される， $\sigma_{m}$ を考慮した修正 MansonCoffin 則を導いた.

$$
\left(\Delta \varepsilon_{p}\right) \cdot N_{f}^{0.533}+C\left\{\left.\left(d \varepsilon_{m} / d N\right)\right|_{N_{f} / 2}\right\} N_{f}^{\beta}=0.673
$$

ただし $C, \beta$ は定数で $\sigma_{m}$ の正負によって異なる.

（5）平均応力作用下の場合にも，前報までの両振
りひずみ制御の場合と同様，き裂伝ば速度 $d l / d N$ はき 裂長さの 1 次に比例し，また微小き裂伝ぱ則を用いて 寿命を予測評価することを明らかにした。

実験の遂行に際し，卒業研究の一部として, 霍田浩 二君 [現, 九州大学大学院], 安成晋一君 [現, 日立製作 所(株)], 福田武君 (現, 九州工業大学大学院〕および 栗山和俊君 [現, 大隈鉄工(株)) の助力を得た. 記して 謝意を表す。

\section{文献}

（1）西谷 ·蓮尾, 機論, 44-377 (昭 53)，1.

(2) Sachs, G., ほか 3 名, Proc. ASTM, 60 (1960), 512.

(3) Yao, J. T.P. and Munse, W. H., ASTM STP, 338 (1962), 5 .

(4) Ohji, K., ほか 2 名, Trans. ASME, Ser. D, 88 (1966), 801.

（5）大路，機誌, 70-576 (昭 42), 36 .

（6）菊川・ほか 3 名、機誌, 70-585 (昭 42), 1495.

(7) Coffin, L. F. Jr, Trans. ASME, Ser. D, 86 (1964), 673.

（8）小林·遠藤, 九州大学态用力学研究所所報, 45 (昭 51), 307.

（9）八木・冨田, 日本造船学会論文集, 138 (昭 50)，410.

（10）白鳥 - 小幡谷, 機論, 32-283 (昭 41), 886 ; 同機論, 35-272 (昭 44), 701, 711: 同, 機論, 38-309 (昭 47), 962.

（11）井手・ほか 2 名，機論, 44-377 (昭 53), 798.

（12）吉田・ほか 2 名, 機論, 45-395, A (昭 54), 769.

（13）吉田・ほか 2 名，機論, 46-407, A (昭 55)，788.

（14）遠藤・坂本，九州工業大学研究報告 (工学)，48 (昭 59), 1.

（15）遠藤・ほか 3 名, 材料, 34-385 (昭 60), 1200.

（16）村上•ほか 4 名，機論, 49-447, A (昭 58), 1411.

（17）原田・ほ加 4 名，機論, 51-464, A (昭60)，1215.

（18）嬯藤・ほか 3 名, 機論, 52 -477, A (昭 61), 1276.

（19）原田・ほか 3 名, 㙨猃, 53-485, A (昭 62), 26.

\section{討論}

〔質問〕井上 達 雄〔京都大学工学部〕

平均応力による繰返変形を考慮した低サイクル疲労 寿命評価について貴重な検討をされたことに敬服す る.

サイクリッククリーブ速度を含む形で提案された式 (6)は，ここで用いられた材料に対する実験式である が,ささらに同様の関係が他の材料や条件についても成 立するとお考えか. また，その物理的ないしは理論的 理由を伺えれば幸いである。ささらに，この形の関係が 成り立つとするとき，材料定数を決めるのにどのよう な実験が必要か。

[回答〕本研究では平均応力作用下で進行する C. C 現象の疲労寿命に及ぼす影響を, 巨視力学因子の 変化と実際の疲労過程 (微小き裂の発生, 伝ぱ) に注目 して検討しました.C.C 現象と力学因子の関係を単純 化して捉えるため, 図 2 に示されるように繰返しに対
して安定な材料を選び，かつ真応力制御方式の疲労試 験を実施し, 検討を加えている.C. C 現象が生起し, 進行すると，それが寿命に影響を及ほすことはこれま での研究でよく知られているが, 式 (6)のように具体 的にその影響を考慮に入れた寿命則は著者らの知見す る限りでは見当たらないようである。式 (6)は C.C 現 象の寿命に及ほす影響を 2,3 節の仮定と実験結果を基 礎にして導出し，陽の形で表現・提案した実験式にす ぎないもちろん，同式の一般性や物理的意義づけに ついては材料定数の簡便な実験的決定の問題も含め, 力学因子と疲労機構の両面に注目しながら今後検討を 重ねる必要があると考えている.

〔質問〕小幡谷 洋 一〔福井大学工学部〕

（1）低サイクル疲れ寿命の評価において微小き裂 伝ぱ則が平均応力の正負によらず適用されるとしてい る (図 8 ) が, その実験的裏づけは $d l l d N \propto l$ の関係が 


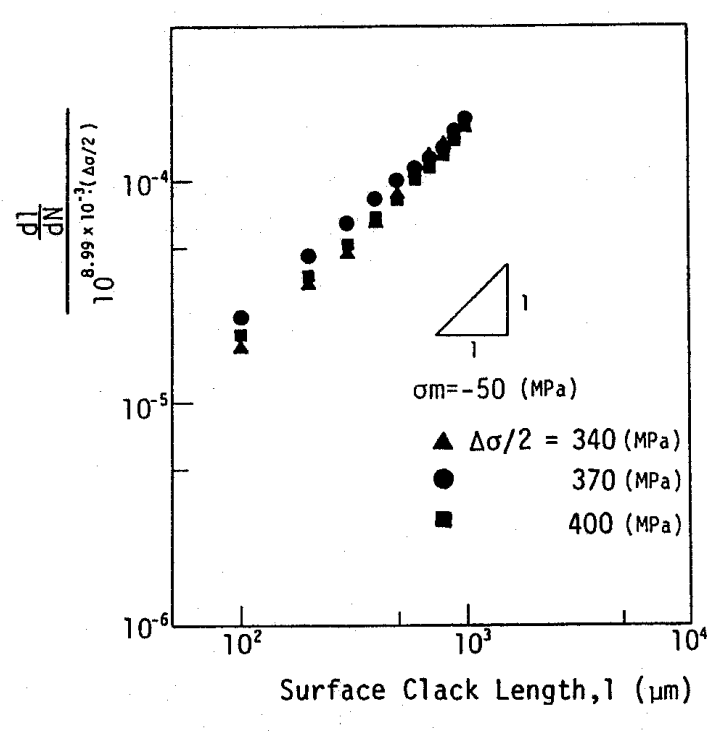

付図 1

成立することにあると思う， $\sigma_{m}<0$ の場合の結果を例 示していただきたい.

（2） $\sigma_{m}$ の正負によらず微小き裂伝ば則が成り立 つことを前提とするならば， $\sigma_{m}$ の正負によってそれ ぞれ異なる材料定数（実験定数）を考慮せざるを得な い修正 Manson-Coffin則の見直しが必要となるので はないか。なぜならば，微小き裂の伝ば挙動に及隹す C. C 現象の効果を明らかにすることのほうが，低サイ
クル疲れの本質を認識するうえでむしろ重要なことと 考えられるので.

[回答〕（1）付図 1 に一例として $\sigma_{m}=$ $-50(\mathrm{MPa}) て ゙ \Delta \sigma / 2$ を 240,370 おょよ゙ $400(\mathrm{MPa}) に$ 変えた際の $d l / d N-l$ 関係を示す. 他の $\sigma_{m}$ の場合にも 同図と同じ傾向（両対数線図上でこう配が 1 の直線） となっている．また， $\sigma_{m}$ の正，0，負に対して一般に $d l / d N=10 C_{l}(\Delta \sigma / 2) \cdot C_{2} l$ (ただし $C_{1}, C_{2}$ は $\sigma_{m}$ によって 定まる定数）なる関係が成立する.

（2）式 (6) \&, 平均応力作用下での C. C 現象進 行の寿命に及ぼす影響を, 微小き裂伝ぱとは無関係に 巨視力学因子に着目して評価し，それを通常の寿命則 に取り込んだ寿命評価式である.式(1)，(2)，(3)よ $\eta, \Delta \varepsilon_{p}$ は $\sigma_{m}, \Delta \sigma / 2$ の関数として与えられるので, 結 局式 (6)で与えられる修正 Manson-Coffin 則は個々 の $\sigma_{m}$ に対してそれぞれ別の形で与えられることにな る.一方, 質問 $(1)$ とも関連して, 微小き裂伝ぱに基づ くき裂伝ぱ則 [式(8)] および寿命評価式 [式(9)] も各 $\sigma_{m}$ に対して別個の形で与えられる. 低サイクル 疲労寿命の大部分が微小き裂の伝ぱ寿命で占められる ことを考えたとき，独立に誘導した二つの寿命評価式 [式 (6)および (9)]がいかなる関連を有するかを検討 することが, 微小き裂伝ぱと C. C 現象の関係を究明 する道につながるものと考えられる。 